\title{
IMPLEMENTASI DIGITAL MARKETING DALAM MEMBANGUN BRAND AWARENESS MENGGUNAKAN METODE OBJECT ORIENTED ANALYSIS AND DESIGN PADA UMKM TEKSTIL KOTA PADANG
}

\author{
Lutfa Fima Jara ${ }^{1}$, Muhammad Reza Putra ${ }^{2}$ \\ Universitas Putra Indonesia Yptk Padang, Indonesia \\ Email : lutfafimajara48@gmail.com muhammad_reza@upiyptk.ac.id
}

\begin{abstract}
Abstrak
Padang yaitu salah kota di Sumatera Barat yang merupakan penghasil produk bahan tekstil terbaik, sehingga tak heran jika Padang menjadi acuan trend fashion dan salah satu destinasi wisata belanja di Sumatera Barat. Penelitian ini bertujuan untuk membangun sebuah aplikasi digital marketing yang dapat membantu semua kalangan masyarakat atau konsumen untuk mencari informasi produk tekstil dan pemesanan bahan tekstil secara online dalam membangun brand awareness, dimana dalam pemesanan bahan tekstil ini masih menggunakan cara manual yang mana konsumen harus datang langsung ke toko untuk memesan produk tekstil. Sehingga dengan cara ini belum efektif dari segi waktu maupun biaya, untuk itu peneliti membuatkan aplikasi yang dapat memudahkan masyarakat atau penumpang dalam pemesanan produk tekstil secara online. Dimana Aplikasi terdiri dari dua bagian yakni, admin menggunakan bahasa pemrograman PHP dan MySQL dengan bantuan software Notepad++ dan Xampp..
\end{abstract}

Kata Kunci : Web, Digital Marketing, PHP, MySQL

\section{PENDAHULUAN}

Industri tekstil merupakan salah satu industri yang berkembang cukup pesat di Indonesia. Indonesia masuk urutan ke 17 sebagai pemasok dari produk tekstil dunia dengan pangsa pasar 1,58 persen. Menurut data kementerian perindustrian pertumbuhan ekspor industri tekstil di Indonesia selama lima tahun terakhir mengalami pertumbuhan 2,28 persen. Pada Tahun 2016 nilai ekspor Indonesia ke dunia mencapai nilai US\$ 12,28miliar. Saat ini informasi mengenai industri tekstil di kota padang masih sangat minim. Dan masalah yang sering terjadi yaitu pada bidang pemasaran produk. Teknologi di era Revolusi Industri 4.0 yang salah satunya.

Digital Marketing merupakan faktor penting yang menjadi solusi yang paling efektif dari permasalahan pemasaran produk yang ada pada industri tekstil ini. Faktor tersebut akan meningkatkan permintaaan konsumen untuk pasar tekstil di kota Padang. Digital marketing adalah memanfaatkan area luas pada media seperti televisi, perangkat mobile hingga Internet, dimana media tersebut akan memberikan informasi tentang berbagai produk yang dipasarkan oleh perusahaan, terutama penekanan tentang merek sebuah produk atau jasa. Digital marketing memudahkan promosi penjualan, seperti penggunaan media sosial yang banyak digunakan oleh para pemasar. Begitu juga dengan KIRBI menggunakan pemasaran melalui digital marketing agar jangkauannya luas dan biaya lebih murah. Keberadaan media sosial menjadi sarana bagi konsumen yang dapat digunakan untuk menyebarkan informasi baik berupa teks, gambar, audio, dan video dengan banyak pihak baik antar perusahaan kepada konsumen atau konsumen pada perusahan (Kotler : 2012).

Brand awereness yaitu dikenal dengan kesadaran merek, maksudnya kemampuan seorang pembeli dalam mengingat kembali (recognize) atau mengenali (recall) bahwa suatu merek merupakan suatu bagian dari produk tertentu. Melalui kesadaran 
konsumen atas suatu brand, maka calon konsumen dapat ingat dan kenal terhadap merek dan

Metode yang digunakan pada penelitian ini yaitu Object Oriented Analysis and Design (OOAD). OOAD adalah metode analisis yang memeriksa requirements dari sudut pandang kelas dan objek yang ditemui dalam ruang lingkup permasalahan yang mengarahkan pada arsitektur software yang didasarkan pada manipulasi objek-objek system atau sub system. OOAD merupakan cara baru dalam memikirkan suatu masalah dengan menggunakan model yang dibuat menurut konsep sekitar dunia nyata. Dasar pembuatan adalah objek yang merupakan kombinasi antara struktur data dan perilaku dalam satu entitas (Hasanuddin , S.Kom, M.Kom : 2016). Terdapat beberapa penelitian sebelumnya yang telah dilakukan, yang berkaitan dengan judul yang penulis angkat salah satunya Penelitian yang dilakukan oleh Femi Oktaviani dan Diki Rustandi (2018), dengan judul "Implementasi Digital Marketing Dalam Membangun Brand Awareness". Penelitian ini menjelaskan mengenai Strategi Digital Marketing yang menggunakan aplikasi e-commerce dan terintegrasi dengan sosial media seperti Intagram, Whatsapp, dan Facebook yamg tujuannya untuk membangun sekaligus meningkatkan Brand Awareness produk dari sebuah UMKM.

Metode Dari masalah diatas penulis ingin mengimplementasikan website digital marketing untuk mempermudah masyarakat untuk mengetahui dan mengenal brand dari produk UMKM tekstil kota Padang. Oleh karena itu penulis membuat sebuah penelitian : "IMPLEMENTASI DIGITAL MARKETING DALAM MEMBANGUN BRAND AWARENESS MENGGUNAKAN METODE OBJECT ORIENTED ANALYSIS AND DESIGN PADA UMKM TEKSTIL KOTA PADANG" memutuskan melakukan pembelian (Oktaviani Femi, Rustandi Diki : 2018).

\section{TINJAUAN LITERATUR}

\section{Konsep Dasar Sistem}

Rekayasa perangkat lunak (Software Engineering) merupakan pembangunan dengan menggunakan prinsip atau konsep rekayasa dengan tujuan menghasilkan perangkat lunak yang bernilai ekonomi yang dipercaya dan bekerja secara efisien menggunakan mesin (Rosa A.S dan M. Shalahuddin, 2013).

Perangkat lunak (software) adalah program komputer yang terasosiasi dengan dokumentasi perangkat lunak seperti dokumentasi kebutuhan,model desain,dan cara penggunaannya (user manual). Sebuah program komputer tanpa terasosiasi dengan dokumentasinya maka belum dapat disebut perangkat lunak (software). Sebuah perangkat lunak juga sering disebut dengan sistem perangkat lunak. Sistem berarti kumpulan komponen yang saling terkait dan mempunyai satu tujuan yang ingin dicapai (Rosa A.S, M. Shalahuddin,2013).

Proses perangkat lunak (software process) adalah sekumpulan aktifitas yang memiliki tujuan untuk mengembangkan atau mengubah perangkat lunak. Secara umum proses perangkat lunak terdiri dari (Rosa.A.S, M.Shalahuddin,2013):

1) Pengumpulan spesifikasi (Specification)

Mengetahui apa saja yang harus dapat dikerjakan sistem perangkat lunak dan batasan pengembangan perangkat lunak.

2) Pengembangan (Development)

Pengembangan perangkat lunak untuk menghasilkan sistem perangkat lunak.

3) Validasi (Validation) 
Memeriksa apakah perangkat lunak sudah memenuhi keinginan pelanggan (customer).

\section{4) Evolusi (Evolution)}

Mengubah perangkat lunak untuk memenuhi perubahan kebutuhan pelanggan (customer).

5) Masukan Sistem (Input)

Energi yang dimasukkan ke dalam sistem disebut masukan sistem, yang dapat berupa pemeliharaan (maintenance input) dan sinyal (signal input).

6) Keluaran Sistem (Output)

Keluaran ini merupakan masukan bagi subsistem yang lain. Seperti contoh sistem informasi, keluaran yang dihasilkan adalah informasi, di mana informasi ini dapat digunakan sebagai masukan untuk pengambilan keputusan atau hal-hal lain yang merupakan input bagi subsistem lain.

\section{7) Pengolah Sistem (Process)}

Suatu sistem dapat mempunyai suatu proses yang akan mengubah masukan menjadi keluaran.

\section{8) Sasaran Sistem (Objective)}

Suatu sistem memiliki tujuan dan sasaran yang pasti dan bersifat deterministik.

Konsep Digital Marketing berasal dari internet dan mesin pencari (search engines) pada situs. Ketika puncak penggunaan internet di tahun 2001, pasar didominasi oleh Google dan Yahoo sebagai search engine optimization (SEO). Dan penggunaan pencarian melalui internet berkembang pada tahun 2006 dan pada tahun 2007 penggunaan perangkat mobile meningkat drastis yang juga meningkatkan penggunaan internet di masyarakat dari berbagai penjuru dunia mulai berhubungan satu sama lain melalui media social (Khan \& Siddiqui, 2011).

\section{Bentuk - Bentuk Pemasaran Digital}

1) Pemasaran Sosial Media Digital adalah pemasaran yang dilakukan melalui media social seperti Facebook, Instragram, Twitter, Google, Pinterest dan Youtube sebagai tempat pemasaran yang cukup menjanjikan bagi pelakunya.
2) Content Marketing memiliki tujuan untuk meningkatkan kesadaran target pasar terhadap merek dengan mengunakan teknik bercerita dan membagikan informasi yang berharga. Content Marketing biasanya lebih dekat ke blogging.

3) Email Marketing pemasaran yang memanfaatkan email sebagai pemasaran digital yang memiliki keefektifannya yang masih bagus. Email Marketing tidak sekedar mengirim email saja akan tetapi kita juga menawarkan nilai, menganalisis data, dan membangun serta memelihara hubungan dengan target konsumen.

4) Iklan pay per clik merupakan pengiklan yang membayar berdasarkan klik yang dilakukan oleh pengguna internet. PPC merupakan salah satu metode untuk mengarahkan lalu lintas ke situs web. Bentuk iklan PPC cukup beragam terdiri dari spanduk web, iklan pop-up, iklan youtube, dan termasuk google adwords. Untuk biaya iklan tergantung tingkat saingan.

5) Search Engine Optimation untuk menempatkan situs web bisnis di dalam daftar terats halaman awal hasil pencarian ketika pengguna internet memasukkan kata - kata kunci tertentu. Cakupan SEO banyak elemen dan memerlukan keahlian dalam mengoperasikan tools tertentu. SEO memiliki keterkaitan dengan Content Marketing dan juga SEO juga mengisi situs tersebut dengan banyak konten yang menarik dan juga berkualitas sehingga lalu lintas situs ke web menjadi ramai.

6) Search Engine Marketing dengan memanfaatkan mesin pencarian, bentuk umum SEM yang sering ditemui adalah google adwords, mengingat google adalah raksasa mesin pencarian di dunia maya. Untuk dapat memasang iklan di google pemasar harus membayar sejumlah uang ke pihak google sebagai syarat kesepakatan dari google. berhubungan dengan bisnis yang kita jalani.

7) E- Commerce perdagangan elektronik kegiatan jual beli barang/jasa atau transmisi dana/data melalui jaringan elektronik berupa internet. Website digunakan sebagai media 
penganti toko offline, website e-commerce juga mencakup berbagai fungsi seperti etalase produk, pemesanan online, dan juga inventarisasi stok, untuk menjalankan fungsi utama e-commerce.

Website

Website merupakan media informasi berbasis jaringan komputer yang dapat diakses dimana saja dengan biaya relatif murah. Web merupakan bentuk implementasi dari bahasa pemrograman web. Sejarah perkembangan bahasa pemrograman web dimulai dengan munculnya HTML (Hyper Text Markup Language), yang kemudian dikembangkan dengan munculnya CSS (Cascading Style Sheet) yang bertujuan untuk memperindah tampilan website. Bahasa pemrograman sudah sangat berkembang saat ini dengan berbagai kemudahan dalam penyajian dan interface yang lebih friendly used. Penyajian yang baik dari suatu bahasa pemrograman akan menghasilkan sebuah web yang dinamis sehingga pengunjung akan lebih mudah mendapatkan informasi yang dibutuhkan. (Wahana Komputer, 2009).

\section{PHP}

PHP (Hypertext Prepocessor) adalah bahasa pemrograman yang berfungsi untuk membuat website dinamis maupun aplikasi web. Berbeda dengan HTML yang hanya bisa menampilkan konten statis, PHP bisa berinteraksi dengan database, file dan folder, contohnya Blog, Toko Online, CMS , Forum, dan Website Social Networking. PHP adalah bahasa scripting, bukan bahasa tag-based seperti HTML. PHP termasuk bahasa cross-platform, ini artinya PHP bisa berjalan di sistem operasi yang berbeda-beda (Windows, Linux, ataupun MAC). Untuk dapat berjalan, PHP membutuhkan web server, yang bertugas untuk memproses file php dan mengirimkan hasil pemrosesan yang akan ditampilkan di browser client. Oleh karena itu, PHP termasuk server-side scripting (script yang diproses di server). (Wahana Komputer, 2009).

SQL merupakan singkatan dari Structured Query Language. SQL atau juga sering disebut sebagai query merupakan suatu bahasa (language) yang digunakan untuk mengakses database. SQL dikenalkan pertama kali dalam IBM pada tahun 1970 dan sebuah standar ISO dan ANSII ditetapkan untuk SQL. Standar ini tidak tergantung pada mesin yang digunakan (IBM, Microsoft atau Oracle). Hampir semua software database mengenal atau mengerti SQL. Jadi, perintah SQL pada semua software database hampir sama.

\section{CSS}

CSS kependekan dari Cascading Style Sheet yang berfungsi untuk mengatur seluruh tampilan halaman web Anda. CSS dapat mengatur posisi layout, jenis dan tipe huruf dengan mudah dan fleksibel, bahkan CSS style juga dapat digunakan untuk mengatur properti yang tidak dapat diatur jika Anda hanya menggunakan HTML, yakni Selector dan Declaration (Elcom, 2013).

\section{Web Server}

Web Server merupakan sebuah perangkat lunak dalam server yang berfungsi menerima permintaan (request) berupa halaman web melalui HTTP atau HTTPS dari klien yang dikenal dengan browser web dan mengirimkan kembali (response) hasilnya dalam bentuk halaman-halaman web yang umumnya berbentuk dokumen HTML.

Untuk menggambarkan system yang dianalisa, penulis menggunakan, alat Bantu perancangan system yang baku, berupa Data Flow Diagram (DFD) atau bisa disebut juga Diagram Aliran Data (DAD), system Flowchart, Entity Relationship Diagram (ERD), kamus data, spesifikasi proses.

\section{UML}

UML merupakan bahasa visual untuk pemodelan dan komunikasi, mengenai sebuah sistem dengan menggunakan diagram dan teks-teks pendukung. UML hanya berfungsi untuk melakukan pemodelan. Jadi pengunaan UML tidak terbatas pada metodologi tertentu, meskipun pada kenyataannya UML palingbanyak digunakan pada metodologi berorientasi objek.

\section{Use Case}

Usecase adalah abstraksi dari interaksi antara sistem dan aktor..Use case bekerja dengan cara mendeskripsikan tipe interaksi antara user sebuah sistem dengan sistemnya sendiri melalui sebuah cerita bagaimana sebuah sistem dipakai. Use Case Diagram kerap digunakan untuk mendokumentasikan dan menjelaskan proses-proses yang berlangsung di dalam sebuah sistem (Rosa-Salahudin, 2011: 130). 


\section{Class Diagram}

Diagram kelas atau class diagram menggambarkan struktur sistem dari segi pendefinisian kelas-kelas

\section{METODOLOGI}

Metodologi Penelitian

Metodologi adalah sebuah prosedur dalam penelitian yang wajib dilakukan penelti (Glesne, 2011). Metode adalah cara untuk mengumpulkan dan menganalisa data. Peneitian merupakan penyelidikan yang sistematis dapat berguna untuk meningkatkan pengetahuan dari suatu masalah yang terjadi. Dari penjelasan diatas dapat disimpulkan secara keseluruhan bahwa metodologi penelitian adalah sekumpulan langkah-langkah atau suatu prosedur yang digunakan peneliti untuk meyelesaikan permasalahan yang terjadi sehingga mendapatkan pengetahuan yang baru (Irawati, Sinaga, \& Lubis, 2018)

\section{Metodologi Penelitian}

Metodologi adalah sebuah prosedur dalam penelitian yang wajib dilakukan penelti (Glesne, 2011). Metode adalah cara untuk mengumpulkan dan menganalisa data. Peneitian merupakan penyelidikan yang sistematis dapat berguna untuk meningkatkan pengetahuan dari suatu masalah yang terjadi. Dari penjelasan diatas dapat disimpulkan secara keseluruhan bahwa metodologi penelitian adalah sekumpulan langkah-langkah atau suatu prosedur yang digunakan peneliti untuk meyelesaikan permasalahan yang terjadi sehingga mendapatkan pengetahuan yang baru (Irawati, Sinaga, \& Lubis, 2018)

Penelitian Pendahuluan

Penelitian pendahuluan adalah langkah awal dalam melakukan penelitian. Dalam tahap ini berisi latar belakang, ruang lingkup penelitian dan manfaat penulisan, tujuan umum sekolah, sejarah sekolah, struktur organisasi, beserta deskripsi Maka tugas masing- masing bagian dalam sekolah dan mengidentifikasi permasalahan yang ada. Dengan penelitian pendahuluan dapat memberikan bukti awal bahwa masalah yang akan kita teliti di lapangan benar- benar ada. Penelitian ini dilakukan dengan cara survey kelapangan dan yang akan dibuat untuk membangun sistem (A.S, Rosa dan M. Shalahuddin. 2014).

pengumpulan data sebelum melakukan penelitian lebih lanjut terhadap objek penelitian.Oleh sebab itu dibutuhkan waktu untuk pengambilan data, waktu penelitian, tempat penelitian, metode penelitian, penelitian lapangan, riset perpustakaan, dan penelitian labor.

Survei Penelitian (StudyLitelatur)

Pengumpulan data dilakukan dengan membaca dan mempelajari buku-buku,jurnal, dan tulisan yang berhubungan dengan penelitian ini. Dalampengumpulan data yang dilakukan dengan menerapkan metode wawancara dengan pihak Penanggung Jawab lapangan Fitria.Spd dan memperoleh dari sekolah tersebut.

Analisa Tujuan Penulisan

Dalam prosesanalisa terdapat dua tahap analisa yang harusdilakukan.Tahapan tersebut adalah:

\section{a. Analisa Data}

Setelah data berhasil dikumpulkan, maka langkah selanjutnya adalah melakukan analisis terhadap data tersebut. Analisa data merupakan suatu usaha untuk mengaji dan mengolah data yang telah terkumpul sehingga diperoleh suatu kesimpulan yang bermanfaat sesuai dengan tujuan penelitian.

\section{b. Analisa Sistem}

Analisis sistem merupakan suatu penguraian dari suatu sistem informasi yang utuh kedalam bagianbagian komponennya dengan maksud untuk mengidentifikasi dan mengevaluasi permasalahanpermasalahan, kesempatan-kesempatan, hambatanhambatan yang terjadi dan kebutuhan-kebutuhan yang diharapkan sehingga dapat diusulkan perbaikan-perbaikannya. diterapkan.Analisa sistem dilakukan untuk mengetahui dan mengembangkan sistem yang sedang berjalan. Sistem ini memerlukan beberapa data yang harus dicantumkan dalam sebuah sistem yang akan dibuat. Beberapa data yang akan dicantumkan antara lain materi,soal latihan,absensi, dan data-data lainnya.Data tersebut akan dimasukkan dalam database agar terorganisasi dengan baik. 
Tahapan perancangan bertujuan untuk membuat penelitian dirancang sesuai dengan tujuannnya, sehingga tidak melenceng dari tujuan penelitian. Akan dilakukan proses pengumpulan data- data yang akan dilakukan untuk mendukung perancangan sistem sebagai objek penelitian. Perancangan akan menggunakan UML (Unified Modeling Languange) sebagai model rancangan agar terorganisasi dan terstruktur dengan rancangan.

Analisa

Analisa adalah proses menemukan permasalahan dan menghasilkan alternatif pemecahan yang relevan. Tujuan tahap analisis adalah untuk mengetahui kebutuhan user berkaitan dengan sistem perangkat lunak yang diinginkan.

Penerapan (Implementasi)

Implementasi ini dilakukan untuk mengetahui spesifikasi komputer untuk menjalankan program dan software apa saja yang dibutuhkan. Merupakan tahap penelitian yang dilakukan untuk mempraktekkan langsung hasil dari analisa yang bertujuan untuk menguji kebenaran proses yang dilakukan secara manual dan dengan program. Program yang digunakan dalam pembuatan akhir ini yaitu web dan database MySql.

\section{Pengujian}

Pengujian merupakan tahapan penelitian yang dilakukan untuk mempraktekkan langsung hasil dari analisa yang bertujuan untuk menguji kebenaran sistem yang dirancang dengan cara memfokuskan pada Fungsionalitas dan aplikasi data mining yang meliputi kesalahan fungsi,interface, dan basisdata:

\section{a. Pengujian aplikasi}

1. aplikasi yang dibuat di uji oleh penulisterlebih dahulu.

2. aplikasi digunakan secara umum oleh user/admin, customer

3. aplikasi djalankan melalui bahasa pemrograman web.

\section{HASIL DAN DISKUSI}

Anda dapat memasukan hasil dan catatan diskusi. Hasilnya disajikan dalam format yang dapat diakses oleh pembaca (misalnya dalam tampilan, tabel, diagram atau teks tertulis). Perhatikan bahwa data mentah biasanya dimasukkan dalam lampiran.

Halaman Home

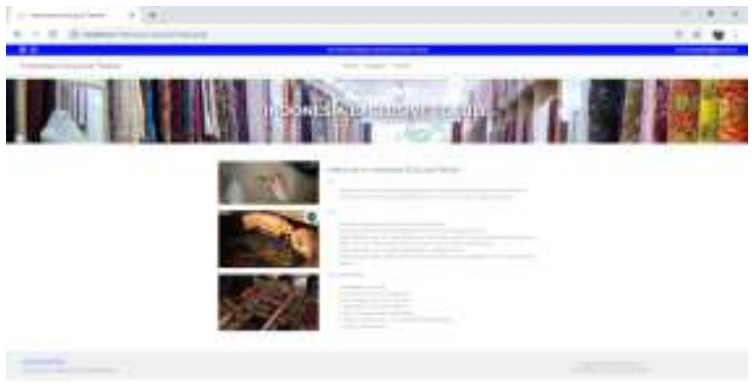

Gambar 1: Halaman Home

Halaman ini berguna untuk menampilkan halaman beranda. Tampilan home merupakan tampilan awal pada halaman menu utama. Pada tampilan menu utama atau home ini terdapat beberapa menu yang dapat diakses oleh user. Pilihan menu yang dapat diakses oleh user antara lain home, produk, kategori produk, sosial media, dan email.

\section{Halaman Login}

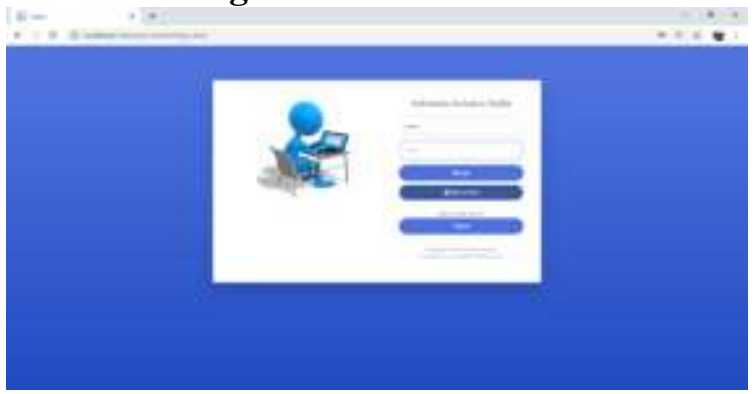

Gambar 2: Halaman Login

Halaman login digunakan untuk dapat masuk ke dalam sistem. Form login berfungsi untuk masuk ke dalam sistem pada Indonesia Textile baik admin maupun

customer. 


\section{Halaman Produk}

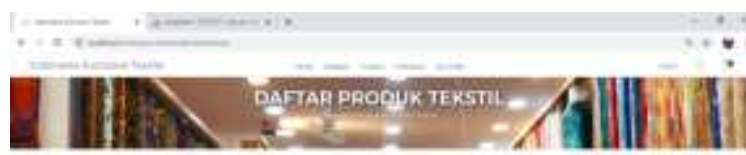

Gambar 3: Halaman Produk

Pada tampilan halaman produk berisikan tentang produk yag disediakan oleh Indonesia Textile

\section{Halaman Checkout}
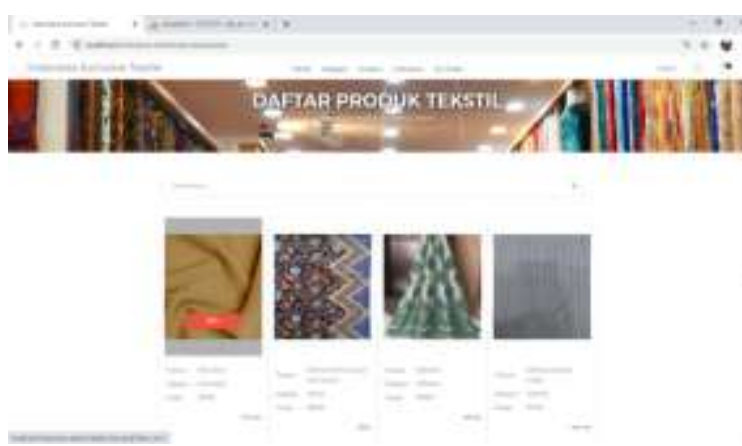

Gambar 4: Halaman Checkout

Pada halaman checkout berfungsi bagi customer untuk melakukan checkout produk saat order produk Indonesia Textile.

\section{Halaman Laporan Pemesanan}

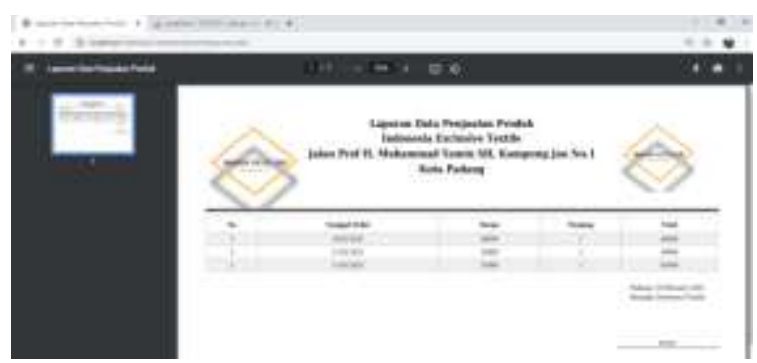

Gambar 5: Halaman Laporan Penjualan

Pada tampilan cetak laporan pemesanan berisikan tentang laporan pemesanan produk pada Indonesia
Textile.

\section{KESIMPULAN}

Berdasarkan hasil pembahasan yang telah diuraikan pada bab- bab sebelumnya, maka penulis dapat menarik kesimpulan sebagai berikut :

1. Diharapkan dengan aplikasi pemesanan produk tekstil berbasis Web ini dapat dikembangkan lagi, yaitu dengan menambah fasilitas pembayaran secara online baik transfer rekening atau paypal dan desain nya sehingga tampilannya lebih cepat dan otomatis.

2. Dengan pengembangan selanjutnya dapat di berikan promo dan diskon produk pada aplikasi yang telah dibuat.

3. Untuk mencegah hal-hal yang tidak diinginkan, perlu ditambahkan proses verifikasi email bagi pengguna yang mendaftar sebagai customer.

\section{DAFTAR PUSTAKA}

[1] AKHIYAR, Dinul; SARI, Vivi Nila; MUHAMMAD, Abulwafa. PEMBANGUNAN DIGITAL MARKETING PEMASARAN PRODUK \& JASA KREATIF PROVINSI SUMATERA BARAT. In: Seminar Nasional Inovasi dalam Penelitian Sains, Teknologi dan Humaniora-InoBali. 2019. p. 99-107. Available at : https://eproceeding.undwi.ac.id/index.php/ino bali/article/download/117/100

[2] Andi. (2009). PHP Programming. Semarang: Penerbit Wahana Komputer.

[3] Andi. 2018 Memanfaatkan Aplikasi Pendukung Android Pada Sistem Operasi Windows ,Yogyakarta.

[4] Febriyantoro, Mohamad Trio, and Debby Arisandi. "Pemanfaatan digital marketing bagi usaha mikro, kecil dan menengah pada era masyarakat ekonomi ASEAN." Jurnal Riset Manajemen dan Bisnis Dewantara (JMD) 1.2 (2018): 61-76. Available at : http://ejournal.stiedewantara.ac.id/index.php/J MD/article/viewFile/175/128.

[5] Hamim, Tohari. 2014. Analisis Serta 
Perancangan Sistem Informasi MelaluiPendekatan UML. Andi Offset, Yogyakarta.on Networking and Security, 2(2)

[6] Kotler, dan Keller. (2012). Manajemen Pemasaran. Edisi 12. Jakarta : Erlangga.Web

[7] Mandala, Eka Praja Wiyata, 2015, Web Programming Project 1. Yogyakarta. CV. ANDI-OFFSET.

[8] Michael, Dave. Strategi e-marketing komunikasi PT Indulakto dalam memperkenalkan produk indomilk melon melalui iklan digital di media sosial= emarketing communication strategy of PT Indolakto to introduce indomilk melon through digital advertising in social media. Diss. Universitas Pelita Harapan, 2018.

[9] Oktaviani, Femi, and Diki Rustandi. "Implementasi digital marketing dalam membangun brand awareness." PRofesi Humas 3.1 (2018): 1-20. Available at : http://jurnal.unpad.ac.id/profesihumas/article/download/15878/8587

[10] Roger, S. Pressman, Ph.D. , 2012, Rekayasa Perangkat Lunak (Pendekatan Praktisi) Edisi 7 : Buku 1 “, Yogyakarta: Andi.

[11] S,Rosa. A. dan M. Shalahuddin. Rekayasa Perangkat Lunak. 2013. Bandung: INFORMATIKA.

[12] Suyanto, M., 2003, Multimedia Alat untuk Meningkatkan Keunggulan Bersaing, Andi Offset, Yogyakarta

[13] Urva, G. Siregar H, M. 2015. Pemodelan UML E-Marketing Minyak Goreng. Jurnal Teknologi dan sistem informasi, Vol 1, No 2, maret 2015:92-101. Available at : http://is.its.ac.id/pubs/oajis/index.php/file/do wnload_file/1464 